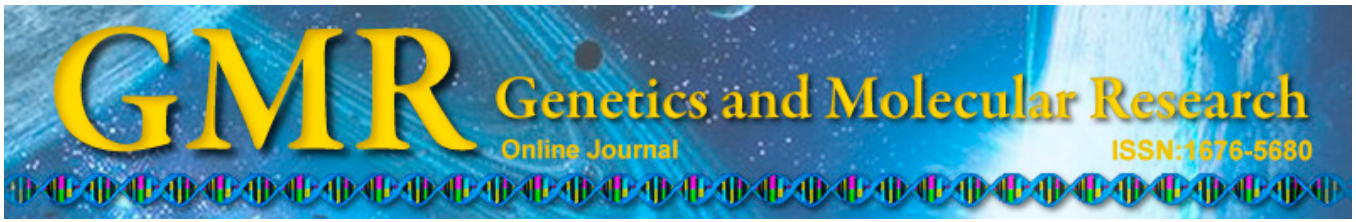

\title{
Diversity and genetic structure of mangaba remnants in states of northeastern Brazil
}

\author{
J.A.E. Amorim ${ }^{1}$, L.R. Mata $^{2}$, A.S. Lédo ${ }^{3}$, V.C.R. Azevedo ${ }^{2}$ and \\ A.V.C. Silva ${ }^{3}$ \\ ${ }^{1}$ Programa de Pós-Graduação em Biotecnologia em Recursos Naturais, \\ Universidade Federal de Sergipe, Aracaju, SE, Brasil \\ ${ }^{2}$ Embrapa Recursos Genéticos e Biotecnologia, Brasília, DF, Brasil \\ ${ }^{3}$ Embrapa Tabuleiros Costeiros, Aracaju, SE, Brasil \\ Corresponding author: A.V.C. Silva \\ E-mail: ana.veruska@embrapa.br
}

Genet. Mol. Res. 14 (1): 823-833 (2015)

Received April 29, 2014

Accepted October 21, 2014

Published February 2, 2015

DOI http://dx.doi.org/10.4238/2015.February.2.7

\begin{abstract}
In this study, we analyzed the genetic diversity and structure of remnants of mangaba populations in states of northeastern Brazil by applying 9 microsatellite markers previously developed to establish conservation strategies for germplasm and species preservation. Six to 20 individuals per population were analyzed, with a total of 94 individuals and 6 populations from the states of Ceará, Pernambuco, and Sergipe, Brazil. The intra-population positive fixation index (f) in all populations indicated inbreeding resulting from the lack of random mating. The mean genetic diversity index values $G_{\mathrm{ST}}, F_{\mathrm{ST}}$, and $R_{\mathrm{ST}}$ estimated for divergence among the 6 populations were 0.14 $(\mathrm{P}<0.05)$, revealing moderate genetic differentiation. The smallest $F_{\text {ST }}$ value $(\mathrm{P} \geq 0.05)$ was observed between the Jacarecoara and Tapera populations (0.005) and the highest between the Barra dos Coqueiros and Jacarecoara populations (0.287). The Jacarecoara population was the most divergent among the populations analyzed. According to analysis of molecular variance results, the largest variation percentage resulted from variability within populations $(83.18 \%)$. Bayesian
\end{abstract}


clustering analysis showed the formation of 2 sets $(K=2)$. Our results are important for developing strategies for in situ conservation of the species, seed collection, and ex situ conservation. For both methods, conservation of the greatest possible genetic variability of the species is essential.

Key words: Genetic variability; Hancornia speciosa; Microsatellite markers; Species preservation

\section{INTRODUCTION}

Genetic diversity is important for sustaining populations of plant species (Wang et al., 2007). One method of evaluating genetic diversity is through molecular characterization, which allows inference of the degree of polymorphism among individuals and populations (Costa et al., 2011) using molecular markers or DNA techniques that are not influenced by environmental conditions and do not show pleiotropic effects (Young et al., 1989).

The genetic structure of plant populations reflect the interactions of many different processes such as the long-term evolutionary history of species (such as changes in distribution, habitat fragmentation, and population isolation), mutation, reproductive, geographical, and ecological isolation, genetic drift, cross system, gene flow, and selection (Thendral Hepsibha et al., 2010; Silva et al., 2012).

Mangaba (Hancornia speciosa Gomes) is a native fruit tree widely distributed in Brazil. It occurs naturally in the areas of coastal tablelands and coastal plains in northeastern Brazil and the Cerrado region of mid-western, northern, and southern Brazil (Moura et al., 2005; Soares et al., 2006).

Because of its high soluble solid content associated with high acidity, giving the fruit good flavor (Soares et al., 2006), mangaba pulp is widely consumed fresh and used as raw material in the preparation of various products such as jelly, jam, syrup, wine, vinegar, and mainly juice and ice cream (Silva et al., 2011). The fruit has large economic potential, which has attracted increasing interest from sectors linked to industry and trade (Ganga et al., 2010).

The state of Sergipe is the largest mangaba producer, particularly the municipalities of Itaporanga D'Ajuda, Pirambu, Estância, Indiaroba, and Barra dos Coqueiros (IBGE, 2012). The collection of fruits from natural populations is an extractive activity performed mainly by the socalled "mangaba pickers" with consequent socio-economic and cultural importance to the state.

Several factors, such as forest fragmentation, real estate expansion, tourism, and increase in areas cultivated with coconut, pasture, and sugarcane (Moura et al., 2005; Silva Junior et al., 2007), have contributed to the significant reduction of naturally occurring growing areas and have exhibited strong pressure on native mangaba tree populations. Therefore, studies examining the genetic diversity and structure of remnant mangaba populations are fundamental for establishing conservation strategies for germplasm and species preservation.

Among molecular markers, microsatellites or simple sequence repeats are the most suitable for polymorphism studies of DNA sequences to examine population genetics because they are codominant, abundant, apparently distributed throughout the genome, and multiallelic; further, the procedure requires the use of only a small amount of DNA, is based on polymerase chain reaction (Buso et al., 2003), and has high reproducibility. 
Few studies have used microsatellite molecular markers to examine the variability in natural mangaba populations (Rodrigues, 2009; Souza et al., 2010; Costa et al., 2012).

In this study, we analyzed the genetic diversity and structure of remnant mangaba populations in 3 states in northeastern Brazil (Ceará, Pernambuco, and Sergipe) using microsatellite markers to assist in the establishment of in situ and ex situ conservation strategies.

\section{MATERIAL AND METHODS}

\section{Sampling, collection, and DNA extraction}

Approximately 6-20 individuals per native $H$. speciosa population were sampled in a total of 6 populations and 94 individuals, 59 from the state of Sergipe (SE), 20 from Ceará (CE), and 15 from Pernambuco (PE), Brazil (Figure 1, Table 1). Because these are remnant populations, the total number of individuals in some cases was exactly the size of populations, making the collection of larger sample sizes impossible. Young leaves without mechanical damage and signs of disease were collected, identified, placed in plastic bags, and transported to the Laboratory of Molecular Biology at Embrapa Coastal Tablelands, in which genomic DNA was extracted based on the CTAB standard protocol (Doyle and Doyle, 1990), modified by Costa et al. (2011). DNA was quantified by comparison with known standard molecular weight using bacteriophage $\lambda$ DNA on a $2 \%$ agarose gel stained with ethidium bromide. Samples were diluted to a concentration of $3.0 \mathrm{ng} / \mu \mathrm{L}$.

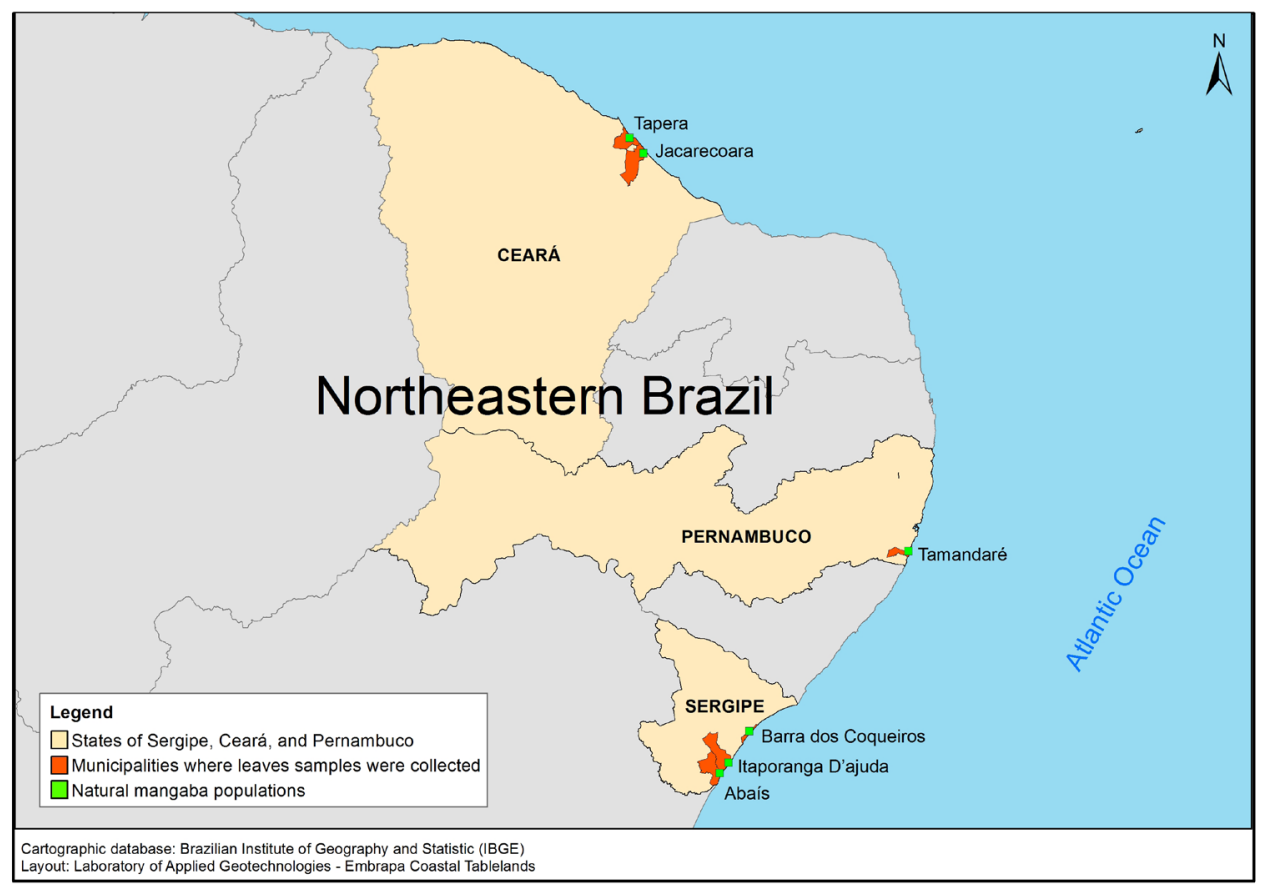

Figure 1. Locations of natural Hancornia speciosa populations in the states of Sergipe, Ceará, and Pernambuco, Brazil, where samples were collected to examine genetic diversity and structure. 
Table 1. Identification, geographical location, and sample size of the 6 Hancornia speciosa populations.

\begin{tabular}{llc}
\hline Populations & Geographical coordinates & No. Individuals sampled \\
\hline Reserva do Caju (SE) & $11^{\circ} 11^{\prime} 6^{\prime \prime} \mathrm{S}$ and $37^{\circ} 11^{\prime} 18^{\prime \prime} \mathrm{W}$ & 19 \\
Abaís (SE) & $11^{1} 8^{\prime} 18^{\prime \prime} \mathrm{S}$ and $37^{\circ} 7^{\prime} 18^{\prime \prime} \mathrm{W}$ & 20 \\
Barrados Coqueiros (SE) & $1^{\circ} 49^{\prime} 10^{\prime \prime} \mathrm{S}$ and $36^{\circ} 56^{\prime} 52^{\prime \prime} \mathrm{W}$ & 20 \\
Jacarecoara (CE) & $4^{\circ} 7^{\prime} 0^{\prime \prime} \mathrm{S}$ and $38^{\circ} 0^{\prime} 34{ }^{\prime \prime} \mathrm{W}$ & 14 \\
Tapera (CE) & $3^{\circ} 6^{\prime} 0^{\prime \prime} \mathrm{S}$ and $38^{\circ} 0^{\prime} 10^{\prime \prime} \mathrm{W}$ & 6 \\
Tamandaré (PE) & $8^{\circ} 43^{\prime} 50^{\prime \prime} \mathrm{S}$ and $35^{\circ} 6^{\prime} 10^{\prime \prime} \mathrm{W}$ & 15 \\
Total & & 94 \\
\hline
\end{tabular}

\section{Genotyping of microsatellites}

Individuals were genotyped at the Laboratory of Plant Genetics, Embrapa Genetic Resources and Biotechnology (Cenargen), Brasília, DF. Overall, 16 pairs of primers developed by Rodrigues (2009) were tested. For each pair of primers, the forward with fluorescence was marked (Table 2). The polymerase chain reaction consisted of the following combination of reagents: $9.0 \mathrm{ng}$ DNA, $0.25 \mathrm{mg} / \mathrm{mL}$ bovine serum albumin, $0.2 \mu \mathrm{M}$ of each primer (forward and reverse), $1 \mathrm{X}$ polymerase chain reaction buffer (10 mM Tris-HC, $\mathrm{pH} 8.3$, and $50 \mathrm{mM} \mathrm{KCl}), 2 \mathrm{mM}$ $\mathrm{MgCl}_{2}, 0.25 \mathrm{mM}$ dNTPs, $1 \mathrm{U}$ Taq DNA polymerase, and sterile ultrapure water to a final reaction volume of $13.0 \mu \mathrm{L}$. For the amplification reactions, the thermocycler used with the following program: denaturation at $94^{\circ} \mathrm{C}$ for $1 \mathrm{~min}, 35$ cycles at $95^{\circ} \mathrm{C}$ for $1 \mathrm{~min}$, annealing temperature specific for each locus (Table 2) for $1 \mathrm{~min}$, extension at $72^{\circ} \mathrm{C}$ for $1 \mathrm{~min}$, and $72^{\circ} \mathrm{C}$ for $10 \mathrm{~min}$.

Multiplex systems consisting of 2-3 loci were assembled using primers marked with different or the same fluorochrome, but with different allele amplitudes. These systems were mixed to $11 \mu \mathrm{L}$ cocktail containing $10 \mu \mathrm{L}$ HiDi formamide and $1 \mu \mathrm{L}$ internal marker developed by Brondani and Grattapaglia (2001). The resulting mixture was denatured for $5 \mathrm{~min}$ at $95^{\circ} \mathrm{C}$. Next, fragments were separated on an ABI automated DNA analyzer 3730 (Applied Biosystems, Foster City, CA, USA).

\section{Data analysis}

The presence of null alleles and their interference in allele frequencies was verified using the Micro-Checker software (Van Oosterhout et al., 2004). A confidence interval of $95 \%$ was used and 1000 Monte Carlo simulations were performed. Equation 1 described by Brookfield (1996) was used to estimate the frequency of null alleles. Linkage disequilibrium and Hardy-Weinberg equilibrium were evaluated based on allelic permutations within populations using the FSTAT software (Goudet, 1995).

The GDA software was used for descriptive analysis of intra-population genetic diversity (Lewis and Zaykin, 2002), estimating the following parameters: allelic number per locus $\left(N_{\mathrm{A}}\right)$, observed heterozygosity $\left(H_{\mathrm{O}}\right)$, expected heterozygosity under Hardy-Weinberg equilibrium $\left(H_{\mathrm{E}}\right)$, and the inbreeding coefficient of populations $(f)$. The consistency of estimates of the inbreeding coefficient was evaluated using the bootstrap method with resampling of 10,000 and confidence interval of $95 \%$ (Weir, 1996). Allelic richness (R) and allele frequencies were calculated using the FSTAT software (Goudet, 1995).

To characterize inter-population genetic variability, Weir and Cockerham (1984) parameters were estimated, including total fixation index $\left(F_{\mathrm{IT}}\right)$, genetic divergence among popu- 
lations $\left(F_{\mathrm{ST}}\right)$, and fixation index within populations ( $F_{\mathrm{IS}}$ is equivalent to the $f$ index), using the FSTAT software (Goudet, 1995). Similarly, other indices similar to $F_{\mathrm{ST}}$ such as $G_{\mathrm{ST}}$ (Nei, 1973) and $R_{\mathrm{ST}}$ (Slatkin, 1995) were determined. The consistency of results was assessed using the bootstrap method for all loci, with a confidence interval of $99 \%$.

An array of pairs of $F_{\mathrm{ST}}$ (Weir and Hill, 2002) was calculated for the 6 populations and the average gene flow was estimated using the following formula: $N \mathrm{~m}=\left(1 / F_{\mathrm{ST}}-1\right) / 4$ (Whitlock and Mccauley, 1999) and the absolute number of migrants among populations (M $=2 \mathrm{Nm}$ ). These analyses were performed using the Arlequin software v. 3.1 (Excoffier et al., 2006). Significance was tested with 1000 permutations. To identify the distribution patterns of variability and genetic differentiation among $H$. speciosa populations, analysis of molecular variance was performed.

Inference of the population structure, number of populations or existing clusters (K), and assignment of sampled individuals to each group was performed using the Structure software v. 2.3.4 (Pritchard et al., 2000). K values ranging from 1-9 were estimated with resampling of 1,000,000 (rejecting the first 250,000) and 20 iterations. To detect the most probable number of groups, we used the $\Delta \mathrm{K}$ statistics described by Evanno et al. (2005).

\section{RESULTS AND DISCUSSION}

Among the 16 microsatellite loci tested, 09 (HS01, HS05, HS06, HS08, HS10, HS11, HS16, HS27, and HS33) allowed amplification of fragments with clear and consistent bands on the agarose gel and showed polymorphisms. Therefore, these loci were further analyzed. The optimal annealing temperature defined for each of the 9 loci ranged from $52^{\circ}-56^{\circ} \mathrm{C}$ (Table 2).

Table 2. Annealing temperature (Ta), reasons for repeats, allele amplitude $\left(\mathrm{bp}^{1}\right)$, and fluorescence of microsatellite primers tested for the genetic characterization of Hancornia speciosa populations (Rodrigues, 2009).

\begin{tabular}{|c|c|c|c|c|}
\hline Primer & $\mathrm{Ta}\left({ }^{\circ} \mathrm{C}\right)$ & Reasons for repeats & Allele amplitude (bp) & Fluorescence \\
\hline HS 01 & 56 & $(\mathrm{GCA})_{6}(\mathrm{TC})_{20}(\mathrm{GCA})_{8}$ & $250-310$ & HEX \\
\hline HS 03 & 56 & $(\mathrm{CT})_{5}(\mathrm{CT})_{6}$ & $120-180$ & 6-FAM \\
\hline HS 05 & 56 & $(\mathrm{GA})_{15}(\mathrm{TGC})_{6}$ & $200-300$ & HEX \\
\hline HS 06 & 54 & $\mathrm{GA}_{14}$ & $100-150$ & HEX \\
\hline HS 08 & 52 & $(\mathrm{CA})_{6}(\mathrm{CT})_{17}$ & $200-250$ & 6-FAM \\
\hline HS 09 & 56 & $(\mathrm{CT})_{7}(\mathrm{CT})_{10}(\mathrm{CT})_{6}$ & $200-300$ & 6-FAM \\
\hline HS 10 & 56 & $(\mathrm{CT})_{14}(\mathrm{CT})_{8}$ & $100-200$ & HEX \\
\hline HS 11 & 56 & $(\mathrm{GA})_{17}$ & $100-200$ & 6-FAM \\
\hline HS 16 & 54 & $(\mathrm{GA})_{12}$ & $100-150$ & 6-FAM \\
\hline HS 17 & 56 & $(\mathrm{GA})_{16}$ & $100-200$ & HEX \\
\hline HS 18 & 56 & $(\mathrm{AG})_{14}^{16}$ & $300-350$ & 6-FAM \\
\hline HS 20 & 56 & $(\mathrm{CT})_{11}^{14}$ & $200-250$ & HEX \\
\hline HS 27 & 54 & $(\mathrm{GA})_{14}$ & $100-150$ & 6-FAM \\
\hline HS 30 & 56 & $(\mathrm{AG})_{10}^{14}$ & $180-200$ & HEX \\
\hline HS 32 & 56 & $(\mathrm{CT})_{9}$ & $200-300$ & 6-FAM \\
\hline HS 33 & 56 & $(\mathrm{AG})_{24}$ & $80-120$ & 6-FAM \\
\hline
\end{tabular}

${ }^{1} \mathrm{bp}=$ base pairs.

No locus showed deviation in the proportions of the Hardy-Weinberg equilibrium and linkage disequilibrium probability tests in all populations showed no associations among loci.

The allelic number per locus $\left(N_{\mathrm{A}}\right)$ appeared to be low for all populations evaluated, with mean values ranging from 3.56-5.56, respectively, for the Tamandaré (PE) and Abaís 
(SE) populations (Table 3), with a difference of $36 \%$ between populations. Therefore, despite the low level, the difference was relevant. This difference may be important for future adaptation of populations with low levels of genetic variability among individuals (Diniz-Filho et al., 2012).

Table 3. Average sample size $(\mathrm{N})$, number of alleles $\left(N_{\mathrm{A}}\right)$, allelic richness $(\mathrm{R})$, expected heterozygosity $\left(H_{\mathrm{E}}\right)$, observed heterozygosity $\left(H_{\mathrm{O}}\right)$, and inbreeding coefficient $(f)$ in relation to the 9 loci analyzed for 6 Hancornia speciosa populations.

\begin{tabular}{lccccccc}
\hline Populations & $\mathrm{N}$ & $N_{\mathrm{A}}$ & $\mathrm{R}$ & $H_{\mathrm{E}}$ & $H_{\mathrm{O}}$ & $f$ & $95 \% \mathrm{CI}$ \\
\hline Reserva do Caju (SE) & 19 & 5.11 & 3.42 & 0.58 & 0.43 & 0.26 & 0.11 to $0.42^{*}$ \\
Abaís (SE) & 20 & 5.56 & 3.31 & 0.57 & 0.50 & 0.12 & 0.03 to $0.25^{*}$ \\
Barrados Coqueiros (SE) & 20 & 4.56 & 2.99 & 0.49 & 0.35 & 0.30 & 0.10 to $0.53^{*}$ \\
Jacarecoara (CE) & 14 & 5.00 & 4.03 & 0.72 & 0.61 & 0.16 & 0.06 to $034^{*}$ \\
Tapera (CE) & 6 & 4.33 & 4.11 & 0.67 & 0.41 & 0.40 & 0.22 to $0.60^{*}$ \\
Tamandaré (PE) & 15 & 3.56 & 2.93 & 0.56 & 0.49 & 0.12 & 0.01 to $0.31^{*}$ \\
Mean & & 4.69 & 3.47 & 0.60 & 0.47 & 0.23 & \\
\hline
\end{tabular}

$95 \% \mathrm{CI}=95 \%$ confidence interval. $*$ Significant at $95 \%$ probability, based on bootstrap resampling of 10,000 .

Despite the variation in sample size among populations, the allelic richness result $(\mathrm{R})$ indicated no direct relationship between sample size and mean alleles per locus, and Tamandaré population (15 individuals) showed the lowest allelic richness (2.93), while the Tapera population (6 individuals) showed the highest allelic richness (4.03) (Table 3). These results suggest that no direct relationship exists between sample size and variability.

The populations with the lowest and the highest genetic diversity among those analyzed were Barra dos Coqueiros and Jacarecoara, respectively, with mean expected heterozygosity $\left(H_{\mathrm{E}}\right)$ values equal to 0.49 and 0.72 and observed heterozygosity $\left(H_{\mathrm{O}}\right)$ values equal to 0.35 and 0.61 . All populations showed $H_{\mathrm{E}}$ values greater than $H_{\mathrm{O}}$ values, and therefore excess homozygotes as expected for a population in Hardy-Weinberg equilibrium (Table 3).

The intra-population positive fixation index $(f)$ shown by all populations indicated inbreeding resulting from a lack of random mating. This can be caused by the crossing of related individuals or self-fertilization.

The mean $H_{\mathrm{O}}, H_{\mathrm{E}}$, and $f$ values obtained in this study are within standards reported for other H. speciosa populations (Costa et al., 2012). However, compared to the results of Souza et al. (2010), we found that mean $H_{\mathrm{O}}$ values were higher than previously reported values, indicating that the population they studied had a lower proportion of heterozygous individuals, resulting in higher $f$ values and lower genetic diversity.

Population genetics studies examining tree species have shown that trees are generally allogamous, but with positive inbreeding coefficients (Azevedo et al., 2007; Santos et al., 2011; Alves et al., 2013).

$F_{\mathrm{ST}}$ values less than 0.05 indicate low genetic differentiation among populations; 0.05 0.15, moderate; 0.15-0.25, high; and above 0.25, very high, according to Wright (1969). The genetic differentiation among populations at the state level (among the 3 states) was highly significant $(\mathrm{P}<0.01)$, with $G_{\mathrm{ST}}, F_{\mathrm{ST}}$, and $R_{\mathrm{ST}}$ values equal to 0.14 (Table 4$)$, revealing moderate genetic differentiation among these populations. Moderate diversity was observed for the average of the 3 populations of Sergipe when the indices were calculated for these populations $\left(G_{\mathrm{ST}}=0.07, F_{\mathrm{ST}}=0.07\right.$, and $\left.R_{\mathrm{ST}}=0.05\right)$. Low genetic differentiation was also verified between the 2 populations from the state of Ceara $\left(G_{\mathrm{ST}}=0.01, F_{\mathrm{ST}}=0.01\right.$, and $\left.R_{\mathrm{ST}}=-0.05\right)$. 
Table 4. Genetic diversity indices among populations $\left(G_{\mathrm{ST}}, F_{\mathrm{ST}}, R_{\mathrm{ST}}\right)$, total fixation index $\left(F_{\mathrm{IT}}\right)$ obtained for different groups of Hancornia speciosa populations.

\begin{tabular}{lcccc}
\hline Group (size) & $G_{\mathrm{ST}}$ & $R_{\mathrm{ST}}$ & $F_{\mathrm{ST}}$ & $F_{\text {IT }}$ \\
\hline States (3) & 0.14 & 0.14 & $0.14^{* *}$ & $0.34^{* *}$ \\
Sergipe (3) & 0.07 & 0.05 & $0.07^{* *}$ & $0.28^{* *}$ \\
Ceará (2) & 0.01 & -0.05 & $0.01^{\mathrm{ns}}$ & $0.26^{* *}$ \\
\hline
\end{tabular}

**Highly significant $(\mathrm{P}<0.01) . \mathrm{ns}=$ not significant.

The comparison results of $F_{\mathrm{ST}}$ for pairs of populations (Table 5) indicated that the lowest $F_{\mathrm{ST}}$ value was observed for Jacarecoara (CE) and Tapera (CE) populations (0.005), which was not significant $(\mathrm{P} \geq 0.05)$. The highest $F_{\mathrm{ST}}$ value was found for pairs of Barra dos Coqueiros (SE) x Jacarecoara (CE) populations (0.287). The Jacarecoara population was the most divergent compared to the other populations, except in comparison to the population from the same state, Tapera. Our results will be useful for supporting conservation strategies aimed at preserving genetically diverse populations. For the ex situ conservation of the greatest possible genetic diversity of the species, these same populations are essential as a source of germplasm to enrich the collection stored in the Mangaba Germplasm Active Bank (BAG Mangaba) at Embrapa Coastal Tablelands. Additionally, these results may guide the selection of parents for use in breeding programs.

Table 5. Divergence array correlating $F_{\mathrm{ST}}$ (genetic divergence index, diagonal below) and $\mathrm{M}=2 \mathrm{Nm}$ (absolute number of migrants, diagonal above) between Hancornia speciosa populations.

\begin{tabular}{|c|c|c|c|c|c|c|}
\hline & Reserva do Caju & Abaís & Barra dos Coqueiros & Jacarecoara & Tapera & Tamandaré \\
\hline Reserva do Caju & - & 44.196 & 5.089 & 1.795 & 3.079 & 9.210 \\
\hline Abaís & $0.011^{\mathrm{ns}}$ & - & 2.988 & 2.295 & 4.446 & 24.824 \\
\hline Barra dos Coqueiros & $0.089^{*}$ & $0.143^{*}$ & - & 1.244 & 1.560 & 3.053 \\
\hline Jacarecoara & $0.218^{*}$ & $0.179^{*}$ & $0.287^{*}$ & - & 102.399 & 2.958 \\
\hline Tapera & $0.140 *$ & $0.101 *$ & $0.243^{*}$ & $0.005^{\mathrm{ns}}$ & - & 7.745 \\
\hline Tamandaré & $0.051 *$ & $0.020^{\mathrm{ns}}$ & $0.141^{*}$ & $0.145^{*}$ & $0.061^{*}$ & - \\
\hline
\end{tabular}

$\mathrm{ns}=$ not significant. $*$ Significant $(\mathrm{P}<0.05)$.

For the absolute number of migrants $(\mathrm{M}=2 \mathrm{Nm})$, the maximum and minimum values were equal to 102.4 and 1.2, respectively, between the Jacarecoara (CE) and Tapera (CE) populations and the Jacarecoara (CE) and Barra dos Coqueiros (SE) populations (Table 5). These results agree with the maximum and minimum $F_{\mathrm{ST}}$ values for pairs of population; the smaller the genetic distance between populations, the higher the gene flow between them (Mangaravite, 2012).

Thus, the Jacarecoara $\mathrm{x}$ Tapera pair of populations showed the lowest genetic divergence, while the Barra dos Coqueiros x Jacarecoara pair was the most divergent. This can be explained by the fact that Jacarecoara and Tapera are geographically close populations. However, Jacarecoara and Barra dos Coqueiros populations are in different states and geographically distant. Although these results suggest a positive correlation between geographical and genetic differentiation, the geographically close Reserva do Caju (SE) and Abaís (SE) populations showed intermediate $F_{\mathrm{ST}}$ values compared with the Tamandare (PE) population.

According to the analysis of molecular variance, the largest variation percentage resulted from variability within populations $(83.18 \%)$, with $10.82 \%$ of variation among states 
and $6.00 \%$ among populations within each state (Table 6). Similar results for variation within H. speciosa populations were observed by Costa et al. (2011) and Moura et al. (2011). High genetic diversity within populations is commonly found in tree species.

Table 6. Genetic variability distribution of Hancornia speciosa populations based on the analysis of molecular
variance of 9 loci.
\begin{tabular}{lrcccc}
\hline Source of variation & df & Sum of squares & Variation components & Variance (\%) & P value \\
\hline Among states & 2 & 47.59 & 0.34 & 10.82 & $<0.001$ \\
Among populations within states & 3 & 25.16 & 0.19 & 6.00 & $<0.001$ \\
Within populations & 182 & 450.12 & 2.63 & 83.18 & $<0.001$ \\
Total & 187 & 522.87 & 3.16 & & \\
\hline
\end{tabular}

Based on Bayesian clustering analysis conducted using the Structure software to evaluate the population genetic structure, the highest $\Delta K$ value converged for $K=2$ (Figure 2), with little variation between values estimated for different repeats, where $\mathrm{K}$ represents the number of genetic groups identified (Evanno et al., 2005).

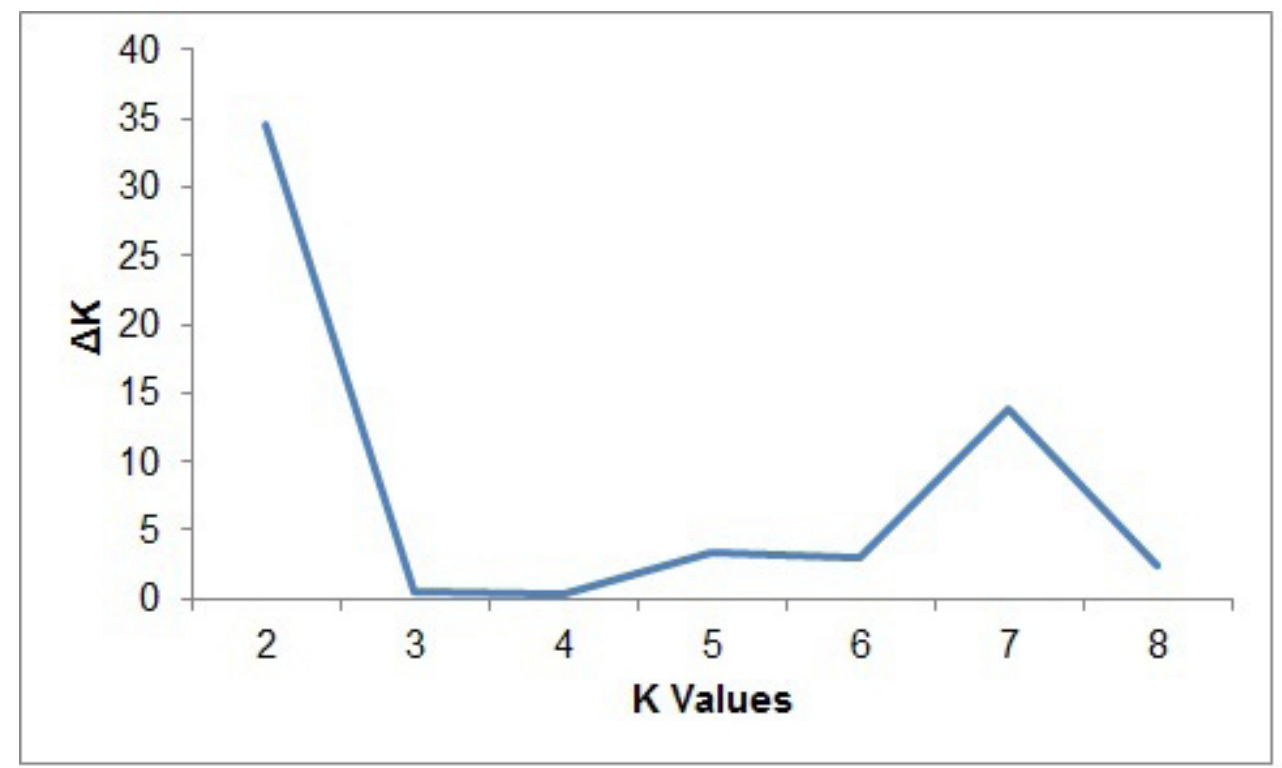

Figure 2. Correlation among $\mathrm{K}$ values (number of genetic groups identified) and $\Delta \mathrm{K}$ for Hancornia speciosa populations.

This result indicates the formation of 2 groups. Populations from Ceará (Jacarecoara and Tapera) were more homogeneous with regard to the distribution of individuals (predominance of red bars) and were very similar to each other, representing a cluster. The Barra dos Coqueiros population was also one of the most homogeneous (predominantly green bars compared to red bars), representing another cluster. However, the other 3 populations were heterogeneous, as a mixture of these 2 clusters (Figure 3 ). This result reinforces the $F_{\mathrm{ST}}$ values 
found, showing almost no differentiation between populations from Ceará $(0.5 \%)$, and high values for Barra dos Coqueiros population compared to these 2 populations (Table 5).

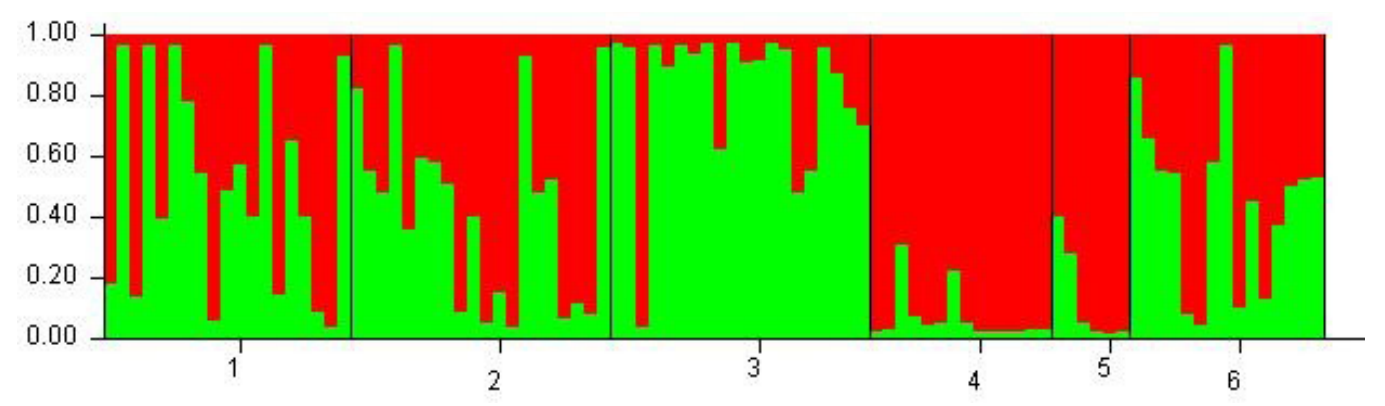

Figure 3. Genetic structure of Hancornia speciosa populations according to Bayesian clustering analysis implemented by the Structure software for $\mathrm{K}=2$, with samples sorted by population: 1 = Reserva do Caju (SE), 2 $=$ Abaís (SE), $3=$ Barra dos Coqueiros (SE), $4=$ Jacarecoara $(\mathrm{CE}), 5=$ Tapera $(\mathrm{CE})$ and $6=$ Tamandaré $(\mathrm{PE})$. Each group is represented by a color and each individual by a vertical bar.

The results obtained for the $H$. speciosa populations revealed moderate inter-population diversity, with the highest estimated variation resulting from divergences within populations. However, significant differentiation was observed when comparing the populations from Ceará with the population from Sergipe, Barra dos Coqueiros, and intermediate differentiation, compared with the Tamadaré (PE), Reserva do Caju (SE), and Abaís (SE) populations. The identification of these 3 groups allows determinating collection strategies in at least 1 population of each of the 3 groups: 1. Jacarecoara or Tapera; 2. Barra dos Coqueiros; 3. Reserva do Caju, Abaís, or Tamandaré.

The in situ conservation of these 3 groups is also essential. Because the population fragments are very small, the recovery of areas with mangaba plantations in these regions should also be encouraged.

This study was the first to analyze genetic diversity and the structure of remnant natural mangaba populations in the states of Ceará, Pernambuco, and Sergipe using microsatellite markers. Thus, because the number of studies of $H$. speciosa species using this type of molecular marker is limited, further analysis should be conducted.

\section{ACKNOWLEDGMENTS}

Fundação de Apoio à Pesquisa e à Inovação Tecnológica do Estado de Sergipe (CAPES/FAPITEC/SE \#07/2012 - PROEF) and Coordenação de Aperfeiçoamento de Pessoal de Nível Superior (CAPES) provided the master's scholarship.

\section{REFERENCES}

Alves MF, Barroso PA, Ciampi AY, Hoffmann LV, et al. (2013). Diversity and genetic structure among subpopulations of Gossypium mustelinum (Malvaceae). Genet. Mol. Res. 12: 597-609.

Azevedo VC, Kanashiro M, Ciampi AY and Grattapaglia D (2007). Genetic structure and mating system of Manilkara huberi (Ducke) A. Chev., a heavily logged Amazonian timber species. J. Hered. 98: 646-654. 
Brondani RP and Grattapaglia D (2001). Cost-effective method to synthesize a fluorescent internal DNA standard for automated fragment sizing. Biotechniques 31: 793-5, 798, 800.

Brookfield JF (1996). A simple new method for estimating null allele frequency from heterozygote deficiency. Mol. Ecol. 5: 453-455.

Buso GSC, Ciampi AY, Moretzsohn MC and Amaral ZPS (2003). Marcadores microssatélites em espécies vegetais. Biotecnol. Cienc. Desenvolv. 6: 46-50.

Costa CF, Collevatti RG, Soares TN and Chaves LJ (2012). Diversidade e Estrutura Genética Espacial Intrapopulacional em Indivíduos Adultos de Hancornia speciosa (Gomes). Anais do IX Congresso de Pesquisa, Ensino e Extensão, Goiânia.

Costa TS, Silva AVC, Lédo AS and Santos ARF (2011). Diversidade genética de acessos do banco de germoplasma de mangaba em Sergipe. Pesq. Agropec. Bras. 46: 499-508.

Diniz-Filho JA, Collevatti RG, Chaves LJ, Soares TN, et al. (2012). Geographic shifts in climatically suitable areas and loss of genetic variability in Dipteryx alata ("Baru" Tree; Fabaceae). Genet. Mol. Res. 11: 1618-1626.

Doyle JJ and Doyle JL (1990). Isolation of plant DNA from fresh tissue. Focus 12: 13-15.

Evanno G, Regnaut S and Goudet J (2005). Detecting the number of clusters of individuals using the software structure: a simulation study. Mol. Ecol. 14: 2611-2620.

Excoffier L, Laval G and Schneider S (2006). Arlequin ver. 3.01: an integrated software package for population genetics data analysis. Comp. Mol. Popul. Gen. Lab. Inst. Zool. Univ. Berne 6: 47-50.

Ganga RMD, Ferreira GA, Chaves LJ and Naves RV (2010). Caracterização de frutos e árvores de populações naturais de Hancornia speciosa Gomes do cerrado. Rev. Bras. Frutic. 32: 101-113.

Goudet J (1995). FSTAT (version 1.2): a computer program to calculate F-statistics. J. Hered. 86: 485-486.

IBGE. Instituto Brasileiro de Geografia e Estatística (2012). Produção da Extração Vegetal e da Silvicultura - 2012. Available at [http://www.sidra.ibge.gov.br/bda/pesquisas/pam/default.asp?o=27\&i=P]. Accessed July 13, 2013.

Lewis PO and Zaykin D (2002). Genetic data analysis: computer program for the analysis of allelic data. Version 1.1. Available at [http://lewis.eeb.uconn.edu/lewishome/software.html]. Accessed June 20, 2013.

Mangaravite E (2012). Estrutura e Diversidade Genética no Complexo Cedrela Fissilis (Meliaceae) Estimadas com Marcadores Microssatélites. Master’s thesis, Universidade Federal de Viçosa, Viçosa.

Moura NF, Chaves LJ, Venkovsky R and Naves RV (2005). Seleção de marcadores RAPD para o estudo da estrutura genética de populações de Hancornia speciosa Gomez. Biosci. J. 21: 119-125.

Moura NF, Moura NF, Venkovsky R and Naves RV (2011). Genetic structure of mangaba (Hancornia speciosa Gomes) populations in the cerrado region of central Brazil. Biosci. J. 27: 473-481.

Nei M (1973). Analysis of gene diversity in subdivided populations. Proc. Natl. Acad. Sci. U. S. A. 70: 3321-3323.

Pritchard JK, Stephens M and Donnelly P (2000). Inference of population structure using multilocus genotype data. Genetics 155: 945-959.

Rodrigues AJL (2009). Desenvolvimento de Marcadores Microssatélites e Estrutura Genética de Hancornia speciosa Gomes (Apocynaceae). Doctoral thesis. Universidade Federal de Goiás, Goiânia.

Santos KL, Ducroquet JPHJ and Nodari RO (2011). Caracterização genética de populações naturais de goiabeira-serrana (Acca sellowiana) com marcadores microssatélites heterólogos. Biotemas 24: 75-83.

Silva AVC, Santos ARF, Wickert E and Silva Junior JF (2011). Divergência genética entre acessos de mangabeira (Hancornia speciosa Gomes). Ver. Bras. Cienc. Agrar. 6: 572-578.

Silva AVC, Rabbani ARC, Sena-Filho JG and Almeida CS (2012). Genetic diversity analysis of mangaba (Hancornia speciosa Gomes), an exotic Brazilian tropical species. Trop. Subtrop. Agroecosyst. 15: 217-225.

Silva Junior JF, Xavier FRS, Lédo CAS and Neves Júnior JS (2007). Variabilidade em populações naturais de mangabeira do litoral de Pernambuco. Magistra 19: 373-378.

Slatkin M (1995). A measure of population subdivision based on microsatellite allele frequencies. Genetics 139: 457-462.

Soares FP, Paiva R, Cravo NR and Oliveira LM (2006). Cultura da Mangaba (Hancornia speciosa Gomes). Boletim Agropecuário 67. Editora UFLA, Lavras.

Souza IP de, Araujo RB and Rodrigues AJL (2010). Estudo da Estrutura Genética de Populações Naturais de Hancornia speciosa Gomes (Apocynaceae), a Partir de Diferentes Parâmetros Biométricos. Anais do VIII Seminário de Iniciação Científica; V Jornada de Pesquisa e Pós-Graduação da UEG, Goiânia. Available at [http://www.prp.ueg.br/sic2010/ apresentacao/trabalhos/pdf/biologicas/seminario/estudo_da_estrutura_genetica.pdf]. Acessed April 19, 2013.

Thendral Hepsibha B, Premalakshmi V and Sekar T (2010). Genetic diversity in Azima tetracantha (Lam) assessed through RAPD analysis. Indian J. Sci. Technol. 3: 170-173.

Van Oosterhout C, Hutchinson WF, Wills DPM and Shipley P (2004). MICRO-CHECKER: software for identifying and correcting genotyping errors in microsatellite data. Mol. Ecol. Notes 4: 535-538.

Wang W, Chen L, Yang P and Hou L (2007). Assessing genetic diversity of populations of top mouth culter (Culter 
alburnus) in China using AFLP markers. Biochem. System. Ecol. 35: 662-669.

Weir BS (1996). Genetic Data Analysis II: Methods for Discrete Population Genetic Data. North Sinauer Associates Inc. Pub., Caroline State University, Sunderland.

Weir BS and Cockerham CC (1984). Estimating F-statistics for the analysis of population structure. Evolution 38: 13581370.

Weir BS and Hill WG (2002). Estimating F-statistics. Annu. Rev. Genet. 36: 721-750.

Whitlock MC and Mccauley DE (1999). Indirect measures of gene flow and migration: $F_{\mathrm{ST}} \neq 1 /(4 \mathrm{Nm}+1)$. Heredity 82 : $117-125$.

Wright S (1969). Evolution and the Genetics of Populations. Vol. 2. The Theory of Gene Frequencies. University of Chicago Press, Chicago.

Young ND and Tanksley SD (1989). RFLP analysis of the size of chromosomal segments retained around the Tm-2 locus of tomato during backcross breeding. Theor. Appl. Genet. 77: 353-359. 